been deduced from sedimentation-diffusion in 20 per cent dioxane $-0.2 \mathrm{~N}$ potassium chloride ; in aqueous solution it is more than 30,000. Moreover, the use of still higher concentrations of dioxane greatly increases the solubility of insulin in the isoelectric region. In 40 per cent dioxane-0.5 $\mathrm{N}$ potassium chloride, 1 per cent insulin can be kept in solution throughout the entire $p \mathrm{H}$ scale.

A detailed account of this work will be published elsewhere. We gratefully acknowledge a research grant from Eli Lilly and Co., Indianapolis. EUGENE FrEDERICQ

Institute of Physical Chemistry,

University of Liège. Oct. 13.

${ }^{1}$ Gutfreund, H., Biochem. J., 40, 432 (1948); 50, 564 (1952).

${ }^{2}$ Gutfreund, H., Biochem. $J$., 42, 554 (1 948).

${ }^{3}$ Oncley, J. L., and Ellenbogen, E., J. Phys. Chem., 56, 85 (1952),

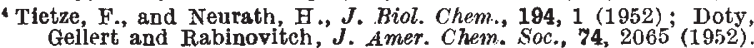

${ }^{5}$ Fredericq, E., and Neurath, H., J. Amer. Chem. Soc., 72, 2684 (1950).

- Fredericq, E., Biochim. Biophys. Acta, 9, 601 (1952).

' Harfenist, K.. J., and Craig, L. C., J. Amer. Chem. Soc., 74, 3087 (1952).

Sanger, F., and Tuppy, H., Biochem. J., 49, 463 (1951).

- Waugh, D. F., J. Amer. Chem. Soc., 70, 1850 (1948).

\section{Apparent Degradation of Wool by Diazomethane Solutions}

ThE action of diazomethane on proteins has been studied by a number of workers, who report that both $\mathrm{O}$ - and $\mathrm{N}$-methylation occur. There is apparently no fission of the peptide chains, although it is stated $^{1}$ that the action of diazomethane on insulin causes a decrease in the cystine content. On the other hand, Kirst ${ }^{2}$ claims that the eystine bridges in wool are unaffected by the reagent, and Herzig and Landsteine $r^{3}$ state that wool is rather more resistant to diazomethane than are other proteins. In most of this earlier work, it was specifically stated that dry proteins and dry ethereal solutions of diazomethane were used. Recently, Kuhn and Ruelius ${ }^{4}$ have shown that diazomethane acts on aqueous solutions of peptides with formation of the corresponding betaines, while serum albumin and ovalbumin in water are slowly converted to insoluble products. We have now found that wool can be extensively degraded by ethereal diazomethane solutions, the product being almost completely soluble in water. The diazomethane, prepared from nitrosomethylurea, is added to the wool over a period of several days, together with small quantities of water. The soluble product conteins no sulphur, and diffuses through 'Cellophane', while the appearance of the wool during the reaction closely resembles that of wool treated with strong alirali.

Diazomethane is known to contain methylamine as an impurity ${ }^{5}$, and our solutions were approximately $0.01 N^{\circ}$ with respect to this compound. However, this weak base alone is without visible attack on wool even at high concentration. Although there is apparently very little action between diazomethane and aliphatic amines in water-free solution (cf. ref. 6), we have found that, when water is present, methylamine, but not higher aliphatic amines, is slowly methylated, producing first trimethylamine and then tetramethylammonium hydroxide, as proved by potentiometric titration and isolation of the corresponding crystalline iodides. The quaternary ammonium hydroxide is a very strong base, and the amount produced from the methylamine impurity in the diazomethane solutions, when absorbed from the ether solution by the small amount of water on the wool, is more than enough to account for the extensive digestion observed. In fact, wool is attacked even by solutions in which the diazomethane has been previously destroyed by the addition of small amounts of water. Samples of diazomethane prepared from $p$-toluenesulphonmethylamide ${ }^{7}$ or from hydrazine and chloroform ${ }^{8}$ also contain basic compounds and show a similar degradation of wool. The removal of the methylamine impurity proved difficult, but partial success was achieved by repeated treatment with either methyl iodide or $p$-toluenesulphonyl chloride followed by distillation. These base-free solutions show no degradative attack on wet wool.

The above results indicate that some caution might be necessary when diazomethane is used in protein studies, for example, in Chibnall's method for the determination of C-terminal residues ${ }^{9}$. Further, it would appear likely that some of the results observed by Head ${ }^{10}$ during a study of the action of diazomethane on cotton and various modified cotton celluloses could be attributed to the presence in the reagent of tetramethylammonium hydroxide.

I. J. O'DONNELI

J. M. SWAN

Biochemistry Unit,

Wool Textile Research Laboratory,

Commonwealth Scientific and

Industrial Research Organization,

Melbourne. Sept. 15.

${ }^{1}$ Matula, J., Biochem. Z., 300, 284 (1939)

${ }^{2}$ Kirst, W., Melliand Textil. Ber., 28, 169 (1947)

${ }^{3}$ Herzig, J., and Landsteiner, K., Monatsh., 39, 369 (1918).

"Kuhn, R., and Ruelius, H. W., Chem. Ber., 85, 38 (1952).

${ }^{5}$ v. Pechmann, H., Ber., 31, 2640 (1898).

Frankel, M., and Katchalski, E., J. Amer. Chem. Soc., 65, 1670 $(1943) ; 66,763$ (1944).

'Backer, H. J., and de Boer, T. J., Proc. K. Ned. Akad. Wet., 54B, 191 (1951).

Staudinger, H., and Kupfer, O., Ber., 45, 505 (1912)

- Chibnall, A. C., and Rees, M. W., Biochem. J., 48, xlvii (1951).

${ }^{10}$ Head, F. S., $J$. Text. Inst., 43, T1 (1952).

\section{Nitrogen Metabolism of Apple Trees}

IN most plants nitrate is the form in which nitrogen is absorbed from the soil and translocated upwards from the roots. Accumulation of nitrate in upper parts of the plant may follow, nitrate reduction and formation of organic nitrogen compounds occurring in many organs. Thomas ${ }^{1}$ showed that the nitrogen uptake of apple trees was atypical in that nitrates could normally be detected in only the finest roots, and suggested that nitrate reduction and formation of amino-acids occurred in these organs. Absence of nitrates from apple leaves has since been confirmed by many workers; but under certain conditions they have been detected ${ }^{2}$.

During work on stock-scion nutrient interrelations in the apple, the nitrogen supply from stock to scion has been investigated. This was done by examining the level and forms of nitrogen present in tracheal sap, extracted by a simplification of the method of Bennett et al..$^{3}$, from one-year old shoots of mature apple trees.

The total nitrogen content of this sap, as determined by a micro-Kjeldahl method, showed considerable seasonal variation. Over the winter months the sap contained approximately $10 \mu \mathrm{gm}$. of nitrogen per $\mathrm{ml}$. There was an increase to $20 \mu \mathrm{gm}$. about three weeks before blossoming, followed by a rise to a peak of $150 \mu \mathrm{gm}$. at flowering (about October 1). This level was maintained for about three weeks, and 